\title{
Muslim Father's Rights in Determining His Minor Child's Conversion to Islam in Malaysia
}

\author{
Dr Zuliza Mohd Kusrin
}

(zuli@ukm.edu.my)

Senior Lecturer of Department of Shariah, Faculty of Islamic Studies, The National University of Malaysia(UKM)

Affliation in Comparative Family Law and Constitutional Human Rights

\section{Associate Professor Dr Salasiah Hanin Hamjah (salhanin@ukm.edu.my)}

Associate Professor of Department of Dakwah, Faculty of Islamic Studies, The National University of Malaysia(UKM) Affliation in Islamic Counselling

\section{Associate Professor Dr Fariza Md Sham}

(farisham@ukm.edu.my)

Associate Professor of Department of Dakwah,

Faculty of Islamic Studies, The National University of Malaysia (UKM)

Affiliation in Dakwah Psychology among Adolescents

\begin{abstract}
Freedom of religion is guaranteed by the Federal Constitution of Malaysia. For children, their rights to freedom of religion are mentioned in Article 12(4) of the Federal Constitution. However, there is conflict of law, i.e. between the civil law and Sharia Law, in some cases involving the child's conversion to Islam, following the conversion of his or her parents. This article aims to discuss on provisions of the Federal Constitution on the child's right to the freedom of religion. The discussion also elu cidate on the father's right in determining his minor child's conversion to Islam. The methodology used in gathering relevant datais content analysis. Data was gathered from Sharia Laws, legal provisions, law joumals and reported cases relevant to the issue. The data has been analyzed descriptively. The discussion discovered that civil court has competent jurisdiction in heaning cases that involves issues of conversion of children following the conversion of only his/her father or mother. In earlier cases of conversion to Islam, it was decided that the minor child's religion is following the religion of his or her converted father/mother. However, in the later cases the court has decided that the religion of the children is remain as the religion of their parents, before the conversion tolslam.
\end{abstract}

Keywords: religion, minor, father, conversion, Islam

\section{INTRODUCTION}

Father is responsible to guide his family to the right path. In the matter of religious belief, Muslim father is responsible to ensure his child being raised up according to Islamic teachings. This article aims to discuss on the issue of father's conversion to Islam and the effect to his minor child's religion, in Malaysian legal perspective. The discussion covers topic 
such as provision on religion and Islam in Malaysia, father's right in determining his minor's child religion and minor's conversion to Islam. Discussion is based on legal provision and decided cases related to the issue.

\section{PROVISION ON RELIGION AND ISLAM IN MALAYSIA}

Article 3(1) of the Federal Constitution states that Islam is the religion of the Federation, but other religions may be practiced peacefully in any part of the Federation. This provision explains the acknowledgment of Islam as the official religion of the Federation while also considering the rights of people of other faiths to practice their respective religions in peace and harmony.

Religions in Malaysia are generally categorized as follows: Islam and "not Islam" (other religions). The definition of the religion of Islam itself was given by the (then) Supreme Court Judge, Tun Salleh Abas in the case of Che Omar Bin Che Soh (1988) 2 M.L.J. 56), where he defined it as a syumul (comprehensive) way of life that encompasses all aspects of life, be it private or public, legal, political, economic, social, cultural, moral or judicial. According to Section 2 of the Selangor Non-Islamic Religions (Control of Propagation Amongst Muslims) Enactment 1988, religions 'other than Islam' means Christianity, Hinduism, Buddhism, Sikhism, Judaism or any variation or form or branch of the aforementioned religions, and includes any beliefs, ideologies, philosophies, groups, or practical systems;

1. Whereby one of the characteristics (of that religion) is the worship of a particular existence or spiritual power or magic, whether real or presumed to be real; or

2. That which admits its purpose or one of its objectives is the attainment of spiritual enlightenment or spiritual presence, i.e. a belief, philosophy, ideology or group or practical system that is not acknowledged in Islam as possessing Islamic elements.

Based on the above legal provision, it is understood that the rights to freedom of certain groups of people to take control of his religious affairs shall be tried in the event that the court agrees that the matter being tried falls into the definition of religion as intended by the Constitution.

Discussion on the right to freedom of religion in Malaysia is specifically provided in Article 11 of the Federal Constitution. Article 11 states that the right of an individual to profess, practice and propagate his religion is subject to general laws concerning public order, safety, health and morals. The provision of Article 11(2) (3) of the Federal Constitution gives freedom to all religious groups to maintain their respective religious affairs, institutions and property for the purpose of their religion and its welfare. Article 11(4) on the other hand states the authority of the state governments and Federal Territory to control and prevent the proliferation of religions other than Islam among Muslims.

A more general view on freedom of religion can be seen by reading Article 3(1) with Articles 10, 8 and 12 of the Federal Constitution. As mentioned earlier, article 3 (1) of the Federal Constitution states on the position of Islam as the religion of the Federation. Article 8 of the Federal Constitution concerns the right to equality in the eyes of the law without discrimination due to differing religions and creeds. However, the exception to this provision is found in clause (3) that states that this right does not apply to personal laws and any other provision that limits promotion or employment due to matters relating to religion. Therefore, based on the aforementioned provision, the actions of a Muslim who enters a polygamous marriage will not be tried for the offense of bigamy. Similarly, the hiring of all-Muslim employees in any state religious department cannot be regarded as an act of discrimination. The guarantee of no discrimination on the basis of religion, creed, or place of birth in the administration of any education foundation and of providing financial aid to any institution of learning, whether public or private, is stated in Article 12 of the Federal Constitution. However, taking into consideration the status of Islam as the religion of the Federation, Article 12(2) explains that the actions of the Federal government or a state government to form or maintain Islamic institutions or assist in Islamic teachings and provide financial aid is not presumed to be in opposition to Article 12 .

Special position of Islam as stated in the Federal Constitution enables it to receive certain legal protections. On the Federal level, the rights to freedom of religion are overseen and controlled by the Sedition Act 1984 (Revised 1969), Printing Presses and Publications Act 1984, Societies Act 1966, Police Act 1967 and the Penal Code. Furthermore, by virtue of the state Islamic Affairs Administrative Enactments, state governments are granted the power to control any sort of Muslim religious activity, specified under the Shariah Administrative Enactment and the Shariah Criminal Offences Enactment. For example, 
section 14(1) of Shariah Criminal Enactment (Selangor) 1995 mentions that state government via the Islamic Religious Council has the power to give credential to an individual to teach Islam among Muslims who are not his family members. If such person teaches Islam to members of the general public without the necessary credential from the Religious Council and is found guilty of doing so, he may be fined. Section 97 of the Administration of Islamic Religious Affairs (State of Selangor) Enactment 2003 stated that Friday prayers are also not allowed to be offered in any place which has not received permission in writing from the State Islamic Religious Council. They also cannot be forced to pay any form of taxation if the income from such tax, whether as a whole or in part, is specifically intended for a religion other than the one they profess. The guarantee to the right of freedom of religion is evidenced by the existence of a provision regarding emergency in Article 150(6A), which prevents the powers of Parliament from being expanded, even during a state of emergency, to matters relating to religion.

Islam as the religion of the Federation in Malaysia received certain privileges as stated in the Federal Constitution. However, it does not mean that Islamic law is comprehensively implemented/enforced in Malaysia. Thus in the issue of conversions to Islam, a conflict of law is occasionally faced by the court in determining the cases that involves conversion of a nonMuslim spouse to Islam in connection with other matter of determining the status of his minor's child religions. This article will further elucidate on the newly converted father's right in determining his minor's child religion, following his new religion.

\section{FATHER'S CONVERSION TO ISLAM IN MALAYSIA}

Conversions to Islam is a common phenomenon among Malaysians. There are cases that the marriage was solemnized according to civil law, later on either the husband or wife converted to Islam. Thus, cases of conversion of either of the civil marriage spouse will definitely raise up several legal issues such as in which court the dissolution of the marriage will be tried, in which court the guardianship and custodianship of the children will be decided and in which court the issue on determination of their child's religion will be ascertained. Even though this article is focusing on the father's right in determining the child's religion, the first and second issues has to be discussed in brief in order to clarify on the issue of the court's jurisdiction in dealing with cases of conversion to Islam in Malaysia.

In Malaysia, there are two types of courts; Shariah Court and Civil Court. The Shariah Court is a trial court at state level that has jurisdiction to hear cases on matrimonial matters of merely Muslim. In contrast to that, civil court is a trial court at federal level that has jurisdiction to hear cases involving Muslim and non-Muslim. Therefore, cases that involve conversions to Islam of either of non-Muslim spouse from civil marriage, has to be tried in the civil court, by referring to the civil law, that is the Law Reform Marriage and Divorce Act 1976. Even though for Muslims, their personal matters should be heard in the Sharia Court, in the cases of conversion, the civil courts will be the appropriate court to hear such cases. It is because Article 8 of the Law Reform Marriage and Divorce Act 1976 states that once the marriage is solemnized under the act, any application deals with the civil marriage, such as dissolution of the marriage and other ancillary relief should be made in the civil courts. Furthermore, since the jurisdiction of the Sharia Court is merely upon the non-Muslim, it will be unjust if the parties cannot bring their cases to either of the courts. The judgement could be seen in the decision made in the case of Nur Aishah Suk bte Abdullah (commat) Asukwinder Kaur a/I Sajhan Singh v. Harjeet Singh ( 2000) 7 Malayan Law Journal, p. 547and Tan Sung Mooi v. Too Miew Kim [1994] 3 Malayan Law Journal, p. 117, that stated :

"A serious injustice will fall upon the couple (the respondent in this case) of the child not of Islam religion, as their only remedy is the civil court, if the High Court has no more jurisdiction as the Shariah Court has no jurisdiction on people who are not Islam religion".

The result of the case obviously shows that in the cases of conversion to Islam which involves either one of the spouse from the civil marriage, it will be adjudicated at Civil Court that will definitely refer to legal provision in the civil family law. In Islam, father as the leader of his family is responsible of guiding his children to the path blessed by Allah SWT. For the father that has converted to Islam, it is his responsibility to preach to his children by encouraging them to enjoin good and prohibiting any wrongdoing (Abdul Karim Zaidan 2001). Allah SWT states in Surah Ali-Imran 3:110, ordering mankind to encourage people to do good and prohibit any wrongdoing and to believe in Him. Hence, the father is the most responsible person to preach them to choose Islam as a religion. The father is considered as an individual that holds trust to guide his family to the Allah's path of lives (Al-Ghazali 2000; Abdul Halim 2010). In Surah Al-Tahrim 66:6, Allah SWT encourage the believers to safeguard their children from Hell. 
In Islam, fathers are held responsible to preserve his child's religion (hifzud din), based on one of the Maqasid Shariah principle. Issue to safeguard the child's belief as well as syahadah is related with the issue of religion conversion. According to provision in the Islamic law, Islamic jurists have unanimously agreed that in cases of both of the parents converted to Islam, any of their children who are not attain puberty or minor will automatically convert to Islam. Problem arises when either of the parents convert to Islam and the other spouse remain to his or her non-Islamic religion. In this case the Islamic jurists have different views concerning the determination on the minor child's religion following the religion of the father or mother to Islam. According to the Shafie and Hanbali sects, the child's religion is Islam, following the religion of either the father or mother that converted to Islam. However, according to the Maliki sect, the child's religion are following the father's religion if the father converted to Islam. (Mohamed Azam Mohamed Adil 2013). The next discussion revolves the determination of the minor child's religion according to the legal context in Malaysia. Does the newly converted father have the right to bring his minor child to profess Islam or does he let them remain in the religion of origin?

\section{MINOR'S CONVERSION TO ISLAM IN MALAYSIA}

In case of minors' conversion to Islam, Articles 12 (3) and (4) of Federal Constitution stresses on the age limit of a person to enable him to convert to another religion, which is eighteen years of age if he doesn't have the permission of his parents or guardian. It means that in Malaysia anybody below the age of 18 is still consider as a minor regardless of they have already reach their puberty. Any pronouncement of Two Kalimah of Syahadah uttered by anybody below the age of 18 must be made with the consent of either parents or guardian.

Generally, the discussion of conversion of minor to Islam in Malaysia could be divided into two situations:

(i) Minors voluntarily converting themselves to Islam

(ii) Minor's conversion following the new religion of their parent or parents.

\section{Minors Voluntarily Converts to Islam}

The provision of Article 11 of the Federal Constitution that allows Muslims to propagate their religion publicly could be seen as an instrument that might attract non-Muslims to learn about the Islamic religion. In Malaysia, the teachings of Islam could be easily accessed through mass media and various programs, as advertised in the television, radio, newspaper and others. In addition to that, the nature of Malaysian society that is comprised of Muslims and non-Muslims, most of them normally living in close proximity, attending the same school, spending their social activities together, might attract them to learn about each other's ways of life or religion, hence a choice to convert to Islam. However, minors are not allowed, even voluntarily, to change their religion without the consent of their parents, as stated in the case of Teoh Eng Huat v. Kadhi Pasir Mas and Anor. [1990] 2 Current Law Journal p. 11, it is an appeal case from the High Court to the Supreme Court. In this case the appellant discovered that his daughter, who had been missing, had been converted to Islam by the first respondent. His daughter was almost eighteen years old and a minor under the civil law. The appellant brought an action in the Kota Baharu High Court seeking a declaration that he, as the lawful father and guardian, has the right to decide the religion, education and upbringing of his infant daughter. The High Court dismissed the application of the appellant. The appellant appealed to the Supreme Court In the meantime, the girl had reached the age of majority. The Supreme Court allowing the appeal, held that:

(1) Under the normal circumstances, non-Muslim parent or guardian has the right to decide the choice of the various issues affecting an infant's life until he reaches the age of majority, which is eighteen years under the civil law.

(2) In the wider interest of the nation, no infant shall have the automatic right to receive instruction relating to any religion other than that his ownwithout the permission of the parent or guardian.

\section{Minor's Conversion Following Their Parent's Conversion}


In a situation where both parents themselves converts to Islam, any of their children under the age of eighteen generally follows their parent's new religion. Meanwhile, children who are already eighteen years old or older have the right to choose their own religion. The case of Viswalingam v. Viswalingam (1980) 1 Malayan Law Journal, p. 300).is an example of the minimum age allowed for any children to decide on their own religion. This is a divorce case due to the conversion of a husband/father to Islam. Atthat time, the ages of their children were nineteen, sixteen and fourteen years old, respectively. Therefore, the children who were under eighteen, then aged sixteen and fourteen, had to follow their father's religion, Islam.

In the case of either the mother or the father converting to Islam, any children below the age of eighteen will follow the religion of their guardian. Therefore, in such cases the person who has the guardianship rights to the children, will have the right to decide their religion, education and upbringing. Meanwhile the party who has the custodianship rights of the children, merely has power referring to the physical development of the child. (T. v. O [1993] Malayan Law Journal, p. 168).

As mentioned by Wu Min Aun, in Family Law, custody is not necessarily co-extensive with guardianship, but neither are they always clearly distinguishable. The word 'guardian' is defined variously in several acts. Section 2 of the Adoption Act 1952 (Rev. 1981) defines the term in relation to child as follows: " ... any person or body of persons other than its natural parents, who has custody of the child...". Section 2 of the Registration of Adoption Act 1952 (Rev. 1981) defines the word guardian as : "... the person having the legal right to the custody of the child ...". The Guardianship of Infants Act 1961, which is the main legislation governing guardianship and custody, does not define the term, but provides in section 3 that: "The guardian of the person of an infant shall have the custody of an infant, and shall be responsible for his support, health and education." The general rule of guardianship rights is stated in Section 5 of the Guardianship of Infants Act 1961 that provides: "... the father of an infant shall be the guardian of the infants person and property...".

The court has the authority to remove, at any time, a guardian whether of the person or the property of the infant, and appoint from time to time another person to be a guardian in his or her place". Section 10, which confers an authority on the court to remove, at any time, a guardian whether of a person or the property of the infant, and, appoint from time to time another person to be a guardian in his or her place. Section 6 states further that it is only where a child has no living father that the mother becomes the guardian of the child's person and property. However, in either case, it is not an absolute right. The High Court retains a discretionary power to appoint some other person to be the guardian, or in the case where there is no living father, to appoint another person to act jointly with the mother as guardian.

There are some examples of cases that differentiate between the rights of guardianship and custody. In the case of Shamala Sathiaseelan v. Dr. Jayaganesh C. Magarajah \& Anor [2004] 2 Malayan Law Journal, p.648, it was an application by the Plaintiff (the wife) for a declaration that the conversion of her two children (the minors) to Islam by the defendant (the husband) without her consent was null and void. The facts of the case were that the husband and wife were married according to Hindu rites and registered under the Law Reform (Marriage and Divorce) Act 1976. The two children to the marriage were minors and were Hindus at the time of birth. The husband converted to Islam and later converted the minor to Islam without the consent and knowledge of the wife. The wife contended that by virtue of an interim order, she had an equal right to decide the religion of the minors. Among the issues for determination were whether consent of a single parent was enough to validate the conversion of a minor to Islam and whether the capacity of the Muslim father to convert the minors were valid. It was held that the husband was the natural father of the two minors and has the legal right to convert the two minors into his new religion, that is Islam. Thus as a construction of Article 12(4) of the Federal Constitution read in conjunction with Section $95(\mathrm{~b})$ of Article 505 , the husband as a natural parent - a Muslim father had the capacity to convert the two minors into Islam. Therefore, the consent of a single parent is satisfied to validate the conversion of the minor's religion. In this case also the court had awarded legal custody jointly to both father and mother with care and control to the mother, subject however to the caveat that the mother would lose the right to care and control it if she is found in any way to influence her children's présent religion.

\section{MUSLIM FATHER'S RIGHTS UPON HIS MINOR'S CHILD RELIGION}

In cases of either of the parent's conversion to Islam, both of them will definitely struggle to gain legal rights of guardianship upon their children in order to ensure that the children will follow either of the parents' religion respectively. According to Section 81 of the Islamic Family Law Act, custodianship rights of minor is with the mother whether during the marriage or at the time of dissolution of marriage. Even though the mother has the utmost rights upon the children, compared to the 
father, section 82 further explains that among the pre-requisite condition required is that the mother has to be a Muslim. Furthermore section 83 of the same act explains the mother will lapse her capability of custodianship if she is not practicing the Muslim religion or becomes an apostasy. The legal provisions show that if the mother is a non-Muslim, the converted Muslim father's rights to gain legal rights upon the child will be considered. However, in most of the decided cases, the civil court will award the right of custodianship to the mother, by reason of protecting the minor's welfare, while the father is awarded with visitation rights.

In the case of Shamala Sathiyayaseelan Iwn. Dr Jeyaganesh C Mogarajah \& Anor ([2004] 2 Current Law Journal, p. 416) the father converted to Islam in 19 November 2002. Six days later, on 25th November 2002, he had brought his children to Majis Agama Islam (Conference of Islamic Religion), to convert them to Islam. Faiza Tamby Chik Judge, while commenting on the case states that the conversion of the children did not automatically happened following their father's conversion. In this case the children was converted to Islam six days later. Based on the provision in Article 12 (4) of the Federal Constitution, it allows the father or mother whom converted to Islam to register their children below the age of eighteen years old as Muslim. The High Court in the case of Nedunchelian a/l V Uthiradam v. Nurshafiqah Mah Singai Annal \& Ors [2005] 2 All Malayan Report, p. 711 also in the opinion that the legal provision that allows the children to change their religion based on consent of either of the parents is in accordance with the interpretation of minors freedom of religion as mentioned in Article 12(4) of the Federal Constitution.

When reference was made to resolve case in Teo Eng Huat v. Kadi Pasir Mas Kelantan \& Majlis Agama Islam ([1990] 2 Malayan Law Journal ( [1990] 2 Malayan Law Journal, p. 228), which also well known as the Susie Teoh case, freedom of religion for children is defined through permission or consent from either the mother or father. The judge in the case obviously defines 'parents' as either the mother or father, which mean giving permission to either the mother or father is enough to enable his or her minor's child to change his or her religion

In the case of Shamala Sathiyayaseelan v. Dr Jeyaganesh C Mogarajah \& Anor, ([2004] 2 Current Law Journal, p.416), a Hindu mother applied a declaration from the court to invalidate the conversion of two of her children to Islam due to the fact that it was made unilaterally, without her consent. Later on the husband then made an objection on the application. The court in deciding the case states that:

"The use of the singular word 'parent" in both art. 12(4) of the Federal Constitution and S. 95(B) of the Administration of Islamic Law (Federal Territories) Act 1933 (Act 505) renders the consent of a single parent enough to validate the conversion of a minor to Islam. Section 5 of the Guardianship of Infants Act (Act 351) on equality of parental rights did not apply to the husband by virtue of s. 1(3) of the same as he was now a Muslim"

In Shamala (2004) case the judge had decided that the plaintiff, a Hindu woman is awarded with the custodianship rights upon both of her children age three and a half year and ten months, whom had been converted to Islam by their Muslim father. The defendant was ordered to pay maintenance for the children, Even though the plaintiff gain the custodianship rights, she is not allowed to change her children's religion. The court also remind her of the order of custodianship will lapse once if it is proven that she has clearly in any ways try to influence her children to convert to another religion other than Islam.

The decision of the above cases was based on understanding that the interpretation of Article 12(4) of the Federal Constitution means consent of either the father or mother is sufficient to allow the minor/children to change their religion. Therefore in almost cases involving conversion of either parents from the civil marriage, the minor children will then following their parents' new religion. The case of Indira Ghandi (2013), the judge's approach has shown that several international norms and human rights is invoked and given priority, to the extent that the legal interpretation of article 12(4) of the Federal Constitution goes beyond the ordinary interpretation as decided in the several earlier cases. Thus the court has decided that based on the basis of nation, religion and gender, the defendant's/father's act of changing his children religion without the mother's consent is considered as against Article 8(2) of the Federal Constitution. The decision of this case clearly shows that the learned judge has made an interpretation that goes beyond the ordinary interpretation of Article 12(4) of the Federal Constitution, as decided in other cases before.

In the recent case of Indira Gandhi a/p Mutho Iwn. Pengarah Jabatan Agama Islam Perak \& Ors ([2013] 5 Malayan Law Journal, p. 555), conversion of her three children aged one year old, ten years old and eleven years old was made by the father per se, without the knowledge of the mother. The appellant (the mother) then applied for a judicial review in the High 
Court of Ipoh, applying a declaration that the endorsement of certificates of conversion to Islam made upon the name of those children are considered as null and void because it was inconsistent with section 106(b) of the Islamic Administration of Islamic Religion Enactment of Perak 2004 and also in contradict with section 5 and 11 of the Guardianship of Infant Act 1961. The appellant also made an application that Article 12(4) of the Federal Constitution is read together with Article 8(2) of the Federal Constitution, concerning the equal rights of the father and mother in this matter. The appellant further made a declaration that the conversion of those children to Islam was not done in accordance to legal procedure.

This case shows that the civil court judge has made a decision in fav or of the applicant and announced that the conversion of those children was done not in accordance with the law. The judge's interpretation among others stated that the decision made by the religious authority in giving consent and verifying the conversion to Islam of the children's religion has no legal validity. It is because Article 11 of the Federal Constitution states that the legal right of every person to profess and practice his or her religion has been infringed. In this case, the court stated that article 11 should be read together with Article 5(1) concerning the freedom of movement and Article 3(1) that refer to other religion that could be practiced in any parts of the Federation.

Tun Abdul Hamid Mohamad, Malaysia's former Chief Justice, while commenting on Indra Ghandi's case states that the case's judgement should be reconsidered based on Sharia Law because the issues of conflicts of laws was clearly present in the subject matter. Even though the result may remain the same, but reconsideration to the Sharia Law needs to be considered. He also commented that the Court should have referred to the human rights issue under the Universal Declaration of Human Rights (UDHR), but needs to be done carefully so that it does not conflict with the principles of Federal Constitution. He continued by voicing his worries with the passion of fellow judges who accepts international norms or priorities the UHRD more that the provision in the Malaysian Federal Constitution itself. (Abdul Hamid Mohamad 2013).

\section{CONCLUSION}

Freedom of religion is guaranteed by law as stated in Federal Constitution of Malaysia. For minors their right to change their religion are subjected to consent of either of the minor's parents. Cases involving conversion of the minor's father/mother were also decided alike. The newly converted Muslim father has legal rights to convert his minor child to Islam. It is also the interpretation of Article 12 (4) on the freedom of religion of minor child, that emphasized on merely consent of either parents is satisfy. However, the decision made in the case of Indira Ghandi 2013 had challenge the legal rights of the father to convert his minor child's religion to Islam, that caused the Muslim father's right to convert his minor child's religion to Islam is restricted.

\section{REFERENCES}

[1] Abdul Halim, Abdullah Muhammad Sacid. (2010). al-Huquq al-mutabadalah baina al-Aba wa al-Abna. Kaherah: Dar al-Kutub al-Misriyah.

[2] Abdul Hamid Mohamad,(2013), Hak Asasi : Peranan dan Fungsi Dari Perspektif Perlembagaan Malaysia, Forum Hak Asasi Sejagat, anjuran Majlis Universiti Islam Malaysia (MUIM) dengan Kerjasama Jabatan Kehakiman Islam Malaysia (JAKIM), Putrajaya: Hotel Marriot

[3] Al-Ghazali, Abu Hamid, Muhammad Bin Ahmad. (2000). Ihya' Ulum al-Din. Kaherah : Dar al-Taqwa li al-Turath.

[4] Izzah Nur Aida Zur Raffar \& Salasiah Hanin Hamjah. Ciri-ciri Personaliti Bapa Dari Perspektif Islam. Prosiding Kolokium Antarabangsa Jejak Warisan IImu Islam (JEWARIS 2015) Malaysia-Brunei.

[5] Karim Zaydan. 2002. Usul al-Dakwah. Ter. Solehan Ayubb. Kuala Lumpur: Pustaka Salam Sdn Bhd.

[6] Mohamed Azam Adil. 2013. Penentuan agama anak-anak. Utusan Melayu (M) Bhd online. Accessed on July 2015. 